\title{
Essence of Leadership in Multiculturalism-Role of White Men in Managing Multicultural Issues
}

\author{
${ }^{1}$ TS Ezaz Ahmed, ${ }^{2}$ Dr. D. Prabhakar \\ ${ }^{I}$ Research scholar ${ }^{2}$ SKIM., Anantapur,
}

\begin{abstract}
Today's global business environment is exciting, evolving, and at the same time challenging: marked by change, complexity, and multiculturalism. The way in which we work has changed dramatically - virtual teams are commonplace, allowing little face-to-face interaction with the people we manage or report to who are based in other countries. Regardless of where our headquarters or domestic offices are located, we interact with global customers and our teams are staffed with international colleagues. Furthermore, our companies are frequently involved in the challenging process of absorbing competitors, being acquired, or being responsible for complicated reorganizations across global borders. These situations lead to management and communication challenges. As a means of effectively addressing these issues, cross-cultural management and change management strategies are imperative. With this combination of strategies, executives have the concepts and tools to successfully bridge cultural differences, maneuver the dynamics of organizational culture, and align and engage people to achieve organizational objectives in a changing business environment.
\end{abstract}

Key words: -Leadership, Multicultural, White Men, Diversity, policies.

\section{Introduction:}

Over the past decade, international and domestic organizations have recognized the critical need for their leaders to become competent in cross-cultural interactions. The transition to a global economy and the increasing diversification of the workforce in the United States support the ongoing need for research and training in this area. Competent multicultural leaders are essential to an organization's success in the global market. Connerley and Pedersen provide a text designed for students in management or business and can also be useful to diversity trainers who are seeking to develop and enhance the multicultural competence of organizational leaders. Their text is a synthesis of workplace research, diversity initiatives, and multicultural counseling competencies in research and theory.

\section{Meaning and definition:}

Leadership has been described as "a process of social influence in which one person can enlist the aid and support of others in the accomplishment of a common task". Other in-depth definitions of leadership have also emerged.

Multiculturalism relates to communities containing multiple cultures. The term is used in two broad ways, either descriptively or normatively. As a descriptive term, it usually refers to the simple fact of cultural diversity: it is generally applied to the demographic make-up of a specific place, sometime at the organizational level, e.g. schools, businesses, neighborhoods, cities, orations. As a normative term, it refers to ideologies or policies that promote this diversity or its institutionalization; in this sense, multiculturalism is a society "at ease with the rich tapestry of human life and the desire amongst people to express their own identity in the manner they see fit." Such ideologies or policies vary widely, including country to country, ranging from the advocacy of equal respect to the various cultures in a society, to a policy of promoting the maintenance of diversity, to policies in which people of various ethnic and religious groups are addressed by the authorities as defined by the group they belong to.

\section{Objectives of the Study:}

- To study the present position of leadership in multiculturalism

- To study the Problems of leadership in multiculturalism

- To suggest certain remedial measures to solve the problems of leadership in multiculturalism

IV.

Methodology of Study:

The study is mainly based on secondary data taken from the reputed Published Sources like Economic Survey, various books and websites on Internet. 


\section{The role of White Men:}

A key concern of executives at the NEW multicultural workforces' conference was the role of white men. The majority of respondents to the post-event survey expressed a desire to see white men fully engaged as part of their firm's diversity and inclusion plan. They said organizations should understand the reality that white men represent the dominant group influencing the culture, "while other team members are considered to be a part of a subordinate group trying to survive by the rules and norms created by white men for white men." The respondents said they were willing to serve as "ambassadors of change" if their organizations were sincerely committed to transforming their corporate culture. 5 These potential ambassadors are ready to help change their companies, Bourgeois said, "but they can't do it without the full support of line managers."White men must engage for diversity to succeed, agrees Dr. Anthony Ipsaro. Sharing power with women and minorities will result in more talent, new ideas and increased corporate creativity, boosting the bottom line for everyone. "White men," he says, "will learn to spend more time at home, with their families, enriching their lives with relationships instead of professional affiliations." "There are certain members of the white male group and others who are never going to get it," Bourgeois says. "Go around them," she advises. "Look for that certain someone in the organization who has the power to make that change and who you believe will make an impact. Focus on the pockets of readiness and partner with them."Two who "get it" appeared at NEW's multicultural workforces conference in 2008. Mike Nathanson is PepsiCo's vice president, financial planning and analysis. Paul Glenn is the human resources manager for the Southwest Division of the Kroger Company and an executive sponsor of the company's employee resource group, Women's Excellence. "Mike and Paul were very frank when they talked about their personal journeys in multicultural workforce management," Bourgeois says. "They are typical of the many men who are vital players in their organizations' diversity efforts." "The workforce has changed but the leadership hasn 't".

\section{Retaining diversity:}

Turnover is a thorny - and costly — problem. The total cost of replacing a management-level employee is estimated to be 200 to 250 percent of that person's annual salary. The problem is even more critical among multicultural managers, where competition for talent can be fierce and where the "revolving door syndrome is particularly evident among women and minorities. Lack of sponsors or mentors was one of the main barriers to success cited by attendees at NEW's multicultural workforces conference. It was also the leading concern of multicultural women who participated at the town hall meetings hosted by Working Mother Media. Forward-looking companies in the CPG/retail industry understand the importance of mentoring to retention. Fifty-six percent of all managers at Procter \& Gamble participate in mentoring, and the firm says that it has helped $P \& G$ 's retention rates stay statistically equal across genders and race and ethnicity. At General Mills 40 percent of employees are engaged in mentoring. PepsiCo has a similar enrollment rate. Mentoring can address some of the key causes of turnover: Feelings of exclusion, being stuck, and of being unappreciated and underutilized. In addition to mentoring, best practices for retaining multicultural workforces include career development, work/life programs, cultural literacy training and community involvement - all of it developed and guided by affinity groups and internal and external diversity councils. Nothing, however, impacts multicultural manager retention more than a clear corporate commitment to promoting diverse talent. At CocaCola, 40 percent of promotions were earned by minorities last year, 56 percent by women. The company is reaping the benefits of this commitment - its management is already 33 percent minority and 48 percent women.

\section{Benefits of a multicultural workforce}

- Increased innovation

- Better insights into consumerism Develop new products and services

- Greater alignment with vendors

- Improved employee morale

- More robust talent pipeline

- Increased retention

- Aligns global teams

- Increased productivity

- Access to new markets

- Increased profitability

\section{Critical Contexts for Multiculturalism:}

\section{* Cultural Studies}

- Analyzes relation of culture to power

- Identifies subcultures and practices of resistance 
- Critiques distinction between "high" and "low" culture

- Roots in Birmingham's Center for Contemporary Cultural Studies and American Civil Rights movement

* Liberation Movements

- Social, political, and/or cultural insurgencies self-consciously aimed to resist or throw-off a dominant power

- Liberation movements around the world aimed at imperialism \& colonialism (Algeria, Hungary, Vietnam,

South Africa, etc.)

- Indigenous liberation movements against nation-state formations (Indians in U.S. \& Mexico, ethnic conflicts

in Balkans, Palestinian struggle in Israel)

- Social movements of "identity politics" (feminism, gay/lesbian, Chicano/a, etc.)

\section{* Post colonialism}

- Uses imperialism/colonialism to contextualize cultural developments

- Indicates historical era of decolonization, esp. after WWII

- Refers to condition of post-colonial subjects, esp. intellectuals, artists, writers, (im)migrants, exiles

- Concerns the production of literary works in postcolonial settings or by postcolonial subjects

- Notes the internationalization of literary languages and forms

* Globalization

- Spread and speed-up of transnational economic structures of exchange

- Technological linkage of global sites of communication

- Mobility of workers, money, cultural goods and services

- The "westernization" of global cultural change

- Cultural forms and practices become commodities bought and solid in an international marketplace

- "Deterritorialization" of cultural forms and practices (no longer linked tightly to localities, regional territories, or homogeneous communities)

* Post nationalism

- Destabilization of nation-state formations by post colonialism and globalization

- Inability to equate nation-state with a "pure" race/ethnicity/culture

- Political emphasis on transnational affiliations (class, race, gender, religion)

- Crisis in literature studies organized by nationalist principles (English, French, German, etc. no longer expressions of the singular identity of a race or nation

- National cultures become "imagined communities" (construction through narrative, invented traditions, stories of origin, symbols, etc)

* Postmodernism

- Critique of artistic and intellectual elements of modernism

-Disruption of traditional cultural forms and practices

Themes of disunity, difference, historical re-memory

- Rejection of a universal model of cultural time

\section{Words of Findings:}

(i)Learning from the Past: When the past is constructed in the bright light of honesty - or at least when everyone's story is told - we can begin reconstructing leadership from a Eurocentric form to one that's more diverse and inclusive. We can construct a new leadership covenant that reflects and respects the history and culture of all Americans.

\section{(ii) I to We: From Individualism to Collective Identity}

a) We cultures share everything.

b) We cultures work together so everyone benefits.

c) We cultures are collective and relish togetherness.

d) No one gets left out of a We culture.

e) We cultures are impeccably inclusive.

f) We culture put benefiting the whole before the individual.

g) In We cultures the I exists only in relationship to others, not as a separate entity.

(iii) The Spirit of Generosity: The purpose of leadership in communities of color is in step with Burns' description - to promote that collective well-being by creating positive social change and securing equal opportunities through a collaborative process that develops and uplifts people. If leaders are to enhance people's well-being, then surely they must nurture a social, political, and economic environment in which people can get their basic needs met, including decent housing, work, education, and health care.

(iv) A Leader among Equals: In collectivist cultures, a leader's authority comes from the group. Leaders are expected to reflect the group's behavior and values. By listening and gathering people's opinions, the leader integrates the group wisdom. The leader must find unanimity within the group first, and then act in concert with 
it. Like a battery, leaders charge people up, facilitate their working together, and assist them in solving problems.

(v) Leaders as Guardians of Public Values: A Tradition of Activism: Leadership in communities of color is inherently a public responsibility to bring people together to address and change the social and economic conditions that affect their lives. Ethnocentric thought and the pull for assimilation pose questions as to whether people can be Americans and still stay connected to their race, culture, country of origin, or ethnic group. Ethnocentricity blinds people to the benefits, customs, traditions, and languages of our rich cultural mosaic. ...The task of preserving and honoring cultural traditions and integrating these into a multicultural mosaic is a key function of leadership in a diverse society.

(vi) Leaders as Community Stewards: Leadership as service integrates the concept that leaders are not motivated by self-interest, personal influence, or power. They accept the mantle of leadership to serve the people, communities and ideals they sought to further. Examples include Nelson Mandela, Marin Luther King Jr., Susan B. Anthony, and Cesar Chavez.

\section{Conclusion:}

A multicultural leadership orientation incorporates many cultural perspectives, appreciates differences, values the unique contributions of diverse groups, and promotes learning from many orientations. People are encouraged to maintain their cultural identity while at the same time participating in and contributing to the larger society. Multicultural leadership is uniquely suited to our mosaic world because it incorporates the influences, practices and values of a variety of cultures in a respectful and productive manner. Multicultural leadership also entails changing organizational structures so that diversity becomes part of the framework and the standard way of operating. This requires a shift from hierarchical pluralism, which dictates that people conform to dominant cultural norms, to egalitarian pluralism, with values and norms that reflect a multicultural perspective.

\section{References:}

[1] Bordas, J. (2007). Salsa, Soul and Spirit: Leadership for a Multicultural Age. Berrett-Koehler Publishers.

[2] Baumann, G. (1999). The multicultural riddle: rethinking national, ethnic and religious identities. London: Routledge.

[3] Casas, J. M., \& Pytluk, S. D. (1995). Hispanic identity development: Implications for research and practice. In J. G. Ponterotto, J. M. Casas, L. A. Suzuki, \& C. M. Alexander (Eds.), Handbook of Multicultural Counseling (pp. 155-180). Thousand Oaks, CA: Sage Publications.

[4] Asante, Molefi Kete. "Multiculturalism: An Exchange" [Response to Diane Ravitch]. American Scholar (Spring 1991). Rpt. Berman, Debating P.C

[5] Escoffier, Jeffrey. "The Limits of Multiculturalism." Socialist Review 91:3-4 (1991)

[6] Goldberg, D.T. (1994). "Introduction: multicultural conditions", pp. 1-41 of Goldberg, D.T. (ed.) Multiculturalism: a critical reader. Oxford: Blackwell.

[7] Jenkins, R. (1967). Essays and speeches. London: Collins.

[8] Kymlicka, W. (1995). Multicultural citizenship: a theory of liberal rights. Oxford: Clarendon Press.

[9] Rouse, R. (1995). "Thinking through transnationalism: notes on the cultural politics of class relations in the contemporary United States". Public Culture. 7(2): 353-402.

[10] Sue, D. W. \& Sue, D. (2003). Counseling the culturally diverse: Theory and practice.New York: John Wiley \& Sons.

[11] www.wikipedia.com 